\title{
Study of the VvMybA1 gene allele state of some colored and uncolored grapevine varieties
}

\author{
Alexander Milovanov", Darja Savenkova, Vitaliy Radchenko, Andrej Zvyagin, and Leonid \\ Troshin \\ Federal State Budget Educational Organization of Higher Education «Kuban state agrarian University \\ named after I. T. Trubilin», 13 str. Kalinina, Krasnodar, 350044, Russia
}

\begin{abstract}
As a result of the work, genetic markers were created that were used to identify alleles of the VvMybAl genes, which control the anthocyanin color of berries in grape varieties. Using these markers, alleles were identified in grape varieties belonging to different ecologicalgeographical groups. In the process of work, alleles were sequenced and compared with the NCBI database in order to identify their state and their belonging to a specific type of structure. In addition, these sequences were compared with each other to reveal the structural features of varieties with and without color of berries. Single nucleotide polymorphisms, structural features, and deletions in the structure of alleles were revealed.
\end{abstract}

\section{Introduction}

The variability of the phenotypic and, accordingly, genotypic diversity of cultivated grapes is truly amazing. At the moment, there are more than 20 thousand varieties and clones, as well as interspecific hybrids. Of course, these varieties were divided and classified according to various characteristics, reflecting their phenotypic and agrobiological characteristics. And, undoubtedly, one of the main features in the classification of a grape plant is the presence of the color of its berries. So, despite the fact that special description methods (descriptors) were developed, the varieties are divided into those with and without color of berries Office International de la Vigne et du Vin.

It is now known that the presence of anthocyanin coloration of berries in grapes is controlled by a tandem of genes located in the second chromosome of the karyotype. This locus is structurally related to the MYBA1 and MYBA2 genes. They are adjacent transcription factors that regulate the color of berries. Also, the karyotype contains the MYBA3 and MYBA4 genes, but they showed practically no effect on the level of expression and synthesis of anthocyanins. Therefore, the main attention is now paid to the first and second genes (VvMybA1 and VvMybA2, respectively) in view of their critical influence on such an important agrobiological trait. And these genes were found to have alleles that differ in structure, expression level and final trait [1].

Various variants of the structure of alleles of these genes are now known for varieties with and without color $[9,10]$. Thus, when studying the features of their structure, various

\footnotetext{
${ }^{*}$ Corresponding author: milovanov1991@mail.ru
} 
forms of alleles were found that lead to different states of berry coloration, for example, VvMybA1a, VvMybA1c, VvMybA1AFL, VvMybA1SUB and VvMybA1BEN [2, 3]. Therefore, at the moment, a fairly large amount of data on the structure of these genes has been accumulated.

As known, one of the distinguishing features of the grapevine is its tendency to spontaneous mutations, which can also affect agrobiological traits [4]. In particular, vegetative propagation of this culture gave even greater diversity and somatic variants of not only loss of color, but also its return were discovered [5].

Despite this, there are still "white spots" in the genetics of cultivated grapes. A large number of allele variants and their structure have been studied in varieties and hybrids that belong to ecological-geographical populations bred outside the Russian Federation, despite the fact that the region of the North Caucasus and the Black Sea basin has a huge phenotypic and genetic diversity of varieties. Therefore, its study and description is of interest in view of the fact that there may be previously unexplored forms of the structure of these genes. This, in turn, will allow for a more detailed biological diversity, as well as replenish the databases for the further development of fundamental and applied science. In general, the identification of unique mutations is also important in order to use this knowledge for the purpose of directed changes in genotypes by various methods, since work in this direction is already being actively carried out $[6,7]$. Moreover, the use of these techniques can be useful not only for cultivated grapes, but also for other plants [8]. In particular, a directed change in the structure of genes for changing the pigmentation of berries seems to be interesting. It is known that the introduction of functional alleles of the VvMybA1 gene can affect the appearance of anthocyanin coloration in various organs of other genetically altered plants $[9,10]$.

Thus, aim of this study was to test the previously constructed primer pairs for amplification of the VvMybA1 gene and to study the allelic state of this gene in varieties with different types of berry color and origin. And after that, to identify the structural features of the amplified alleles.

\section{Materials and methods}

The studies were carried out in 2020-2021. in the laboratory of the Department of Biotechnology, Biochemistry and Biophysics of the Federal State Budgetary Educational Institution of Higher Education "KubSAU". Five well-known grape varieties were selected as the objects of research: Muscat White, Budai Shuli, Plechistik, Dostoiny and Avgustin. The varieties were selected according to their ability to accumulate anthocyanin color in berries (Avgustin, Budai Shuli, Muscat White - with uncolored berries and Plechistik, Dostoiny - with colored berries).

DNA isolation was carried out from dried apical leaves. Lyophilization was carried out using Martin Christ Lyophilizer (Martin Christ). The dried tissues were then crushed with metal balls using a GT200 Grinder (Green Research Scientific). DNA extraction from the tissue powder was performed using the DNeasy Plant Mini Kit (QIAGEN). Evaluation of the quality and quantity of isolated DNA was carried out using IMPLEN NP80 nanophotometer (IMPLEN).

For PCR, we have developed primers that include the $1277 \mathrm{bp}$ region of the nuclear grape genome on the second chromosome, locus VvMybA1. The primers were developed based on the PN40024 reference genome, accession: GCA_000003745.

In the process of designing primers, we used the programs OligoCalc [9] and Primer3 [10].

\section{Primers:}

5'-GAGTTTGCATCCACTGCTCA-3' - Forward primer. 
5'-GGAAGCCAGTAATGCACCAT-3' - Reverse primer.

A PCR mixture with a volume of $25 \mu$, including: $20 \mathrm{ng}$ of DNA, $200 \mathrm{mM}$ DNTP, 0.2 $\mathrm{mM}$ of each primer and 1 unit of DNA polymerase. The following parameters were used for PCR: initial denaturation $95{ }^{\circ} \mathrm{C}-3$ minutes, then 35 cycles $94{ }^{\circ} \mathrm{C}-30$ seconds; $57{ }^{\circ} \mathrm{C}-$ 30 seconds; $72{ }^{\circ} \mathrm{C}-30$ seconds; and $72{ }^{\circ} \mathrm{C}-10$ minutes for final elongation. Verification of the PCR results for the presence of expected fragments was carried out in $2 \%$ TAE agarose gel, separation of amplification products in a horizontal electrophoresis chamber (Helicon) with the following parameters: $15 \mathrm{~min}, 150 \mathrm{~V}$ and $150 \mathrm{~A}$.

PCR fragments were separated on $2 \%$ agarose gel in TAE buffer. Obtained fragments were cutted out from the gel plate, isolated and purified using the Cleanup Standart kit (Evrogen RU). The concentration of the PCR sample was measured using IMPLEN NP80 nanophotometer and was brought to a volume of $6 \mu \mathrm{l}$ with deionized water, containing the purified PCR fragment in the amount of $30 \mathrm{ng} / \mu \mathrm{l}$. Sequencing was carried out by Evrogen RU company using our forward and reverse PCR primers.

Reverse sequences were reversed and complemented using Reverse-Complement online tool (http://reverse-complement.com/). Initial analysis for the compliance with expected result was performed by searching the sequence in the NCBI [11] database using BLAST [12]. The obtained DNA and protein sequences were aligned using standard parameters in the ClustalO program [13], VIENNA formats (for aligning in fasta format) [14]. Aligned sequences were analyzed using the MView interface. Phylogenetic relationships between the studied amino acid sequences were established using the MEGA7 program [15] using the Maximum Likelihood method, with the Jones-Taylor-Thornton model (999 bootstrap).

\section{Results and discussion}

As a result of the PCR, we obtained five amplified fragments that did not differ in size. Thus, we can conclude that these pairs of primers were selected specifically for the genomes selected for study. Then these fragments were excised from the gel, purified and sequenced. The resulting reverse sequences were reversed and complemented, after which they were aligned with each other to get an idea of the fragment that overlaps. Further, the obtained DNA sequences were combined into one and compared between each other (Figure 1).

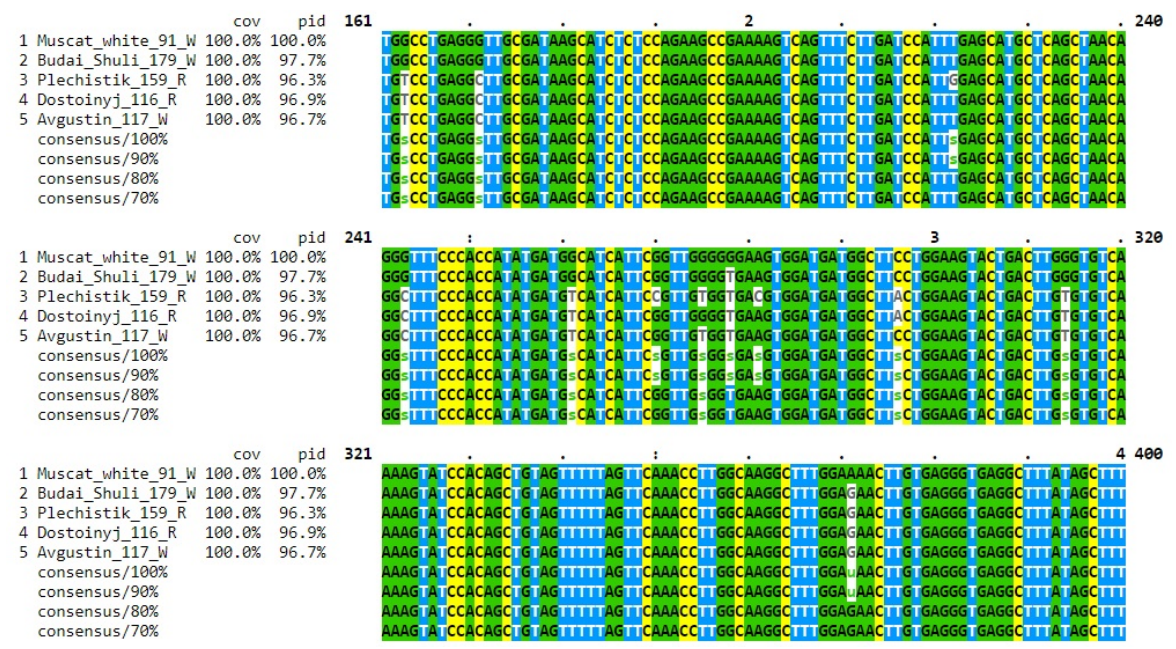

Fig. 1. Aligned sequences of the studied varieties 
As we can see from Figure 1, the amplified sequences have nucleotide substitutions, and some of them are unique for the varieties. Therefore, in order to check the state of the loci, we carried out a comparison with the existing sequences in NCBI. Interestingly, all accessions, with the exception of the Plechistik cultivar, were found to be similar with the gene structure of the Jingxiu cultivar (JX470201.1). While variety Plechistik had a match with the Teinturier-DEU456 clone (MT482341.1). It is important to note that both varieties have colored berries. Despite this, it was found that all genotypes, except for varieties with anthocyanin berry color, have changes in the structure of alleles (Table 1).

Table 1. Coincidences in the structure of alleles and NCBI numbers

\begin{tabular}{|c|c|c|c|}
\hline Variety & Name of accession & $\begin{array}{c}\text { Percentage of } \\
\text { similarity }\end{array}$ & $\begin{array}{c}\text { Accession } \\
\text { number }\end{array}$ \\
\hline $\begin{array}{l}\text { Muscat } \\
\text { white }\end{array}$ & $\begin{array}{l}\text { Vitis vinifera cultivar Jingxiu myb- } \\
\text { related transcription factor (MYBA1) } \\
\text { gene }\end{array}$ & $96.69 \%$ & JX470201.1 \\
\hline $\begin{array}{l}\text { Budai } \\
\text { Shuli }\end{array}$ & $\begin{array}{l}\text { Vitis vinifera cultivar Jingxiu myb- } \\
\text { related transcription factor (MYBA1) } \\
\text { gene }\end{array}$ & $98.44 \%$ & JX470201.1 \\
\hline Plechistik & $\begin{array}{l}\text { Vitis vinifera isolate VvmybA1t5 } \\
\text { transcription factor MybA1 (mybA1) } \\
\text { gene }\end{array}$ & $100 \%$ & MT482341.1 \\
\hline Dostojnyj & $\begin{array}{l}\text { Vitis vinifera cultivar Jingxiu myb- } \\
\text { related transcription factor (MYBA1) } \\
\text { gene }\end{array}$ & $99.61 \%$ & JX470201.1 \\
\hline Avgustin & $\begin{array}{l}\text { Vitis vinifera cultivar Jingxiu myb- } \\
\text { related transcription factor (MYBA1) } \\
\text { gene }\end{array}$ & $100.00 \%$ & JX470201.1 \\
\hline
\end{tabular}

Therefore, we made a comparison with the amino acid sequences available in the NCBI. As a result, similarities and differences were identified (Table 2).

Table 2. Comparison of DNA sequences of the studied varieties with the available amino acid sequences

\begin{tabular}{|l|l|r|c|}
\hline \multicolumn{1}{|c|}{ Variety } & \multicolumn{1}{|c|}{ Name of accession } & \multicolumn{1}{c|}{$\begin{array}{c}\text { Percentage of } \\
\text { similarity }\end{array}$} & $\begin{array}{c}\text { Accession } \\
\text { number }\end{array}$ \\
\hline $\begin{array}{l}\text { Muscat } \\
\text { white }\end{array}$ & $\begin{array}{l}\text { transcription factor MybA [Vitis } \\
\text { vinifera] }\end{array}$ & $83.82 \%$ & ABB87009.1 \\
\hline $\begin{array}{l}\text { Budai } \\
\text { Shuli }\end{array}$ & MybA1 [Vitis vinifera] & $92.31 \%$ & ABD72953.1 \\
\hline Plechistik & $\begin{array}{l}\text { transcription factor MybA [Vitis } \\
\text { vinifera] }\end{array}$ & $98.27 \%$ & ABB87014.1 \\
\hline Dostojnyj & MybA1 [Vitis vinifera] & $97.69 \%$ & ABD72954.1 \\
\hline Avgustin & MybA1 [Vitis vinifera] & $95.86 \%$ & ABD72953.1 \\
\hline
\end{tabular}

The sequence of amino acids in the studied varieties showed that the varieties with the color of berries had the greatest similarity. While the white berry varieties had a low similarity, which is obvious. Also, comparing of amino acid sequences revealed that varieties Plechistik and Dostoyny have several unequal substitutions, which obviously did not affect the final trait. For the rest of the varieties, it can be concluded that these changes may be the reason for the lack of color. Despite this, there are also other reasons for the loss 
of color in varieties, for example, changes in the structure of the VvMybA2 gene, so it is difficult to make a precise conclusion about the studied varieties for now.

\section{Conclusion}

As a result of our work, we tested new genetic markers aimed at amplifying the VvMybA1 gene region in grapes. Further, regions of this gene were amplified in five known cultivars and sequenced. After that, the areas were compared for compliance with the existing sequences in the NCBI.

A comparison of the sequences with each other showed the differences in the structure, which were expressed in nucleotide substitutions. Comparison with the accessions deposited with the NCBI showed that four out of five accessions had the greatest similarity to JX470201.1, while the Plechistik variety showed similarities to MT482341.1. Differences were found between sequenced and deposited samples, expressed in nucleotide substitutions.

Comparison with amino acid sequences showed that there are also significant differences between white berry varieties and varieties with colored berries. These differences were expressed in unequal amino acid substitutions in the sequences. Nevertheless, unequal substitutions were found in varieties with the colored berries as well. Despite their presence, these varieties have color, therefore, these changes were not significant.

Acknowledgments. Scientific work was supported by RFBR and Administration of Krasnodar Region, grant № 19-44-233003.

\section{References}

1. V. Ferreira, I. Castro, D. Carrasco, O. Pinto-Carnide, R. Arroyo-García, J. Berry Res., 3, 147-162 (2018) https://doi.org/10.3233/JBR-170289

2. V. Ferreira, F. Fernandes, D. Carrasco, M. Gonzalez Hernandez, O. Pinto-Carnide, R. Arroyo-García, P. Andrade, P. Valentão, V. Falco, I. Castro, Food Res. Int., 149-161 (2017) https://doi.org/10.1016/j.foodres.2017.03.050

3. P. Carbonell-Bejerano, C. Royo, R. Torres-Pérez, J. Grimplet, L. Fernandez, J. Manuel Franco-Zorrilla, D. Lijavetzky, E. Baroja, J. Martínez, E. García-Escudero, J. Ibáñez, J. M. Martínez-Zapater, Plant Physiol., 175(2), 786-801 (2017) https://doi.org/10.1104/pp.17.00715

4. V. Ferreira, J.T. Matus, O. Pinto-Carnide, D. Carrasco, R. Arroyo-García, I. Castro, BMC Genomics, 20(1), 952 (2019) https://doi.org/10.1186/s12864-019-6237-5

5. L. Dalla Costa, M. Malnoy, D. Lecourieux, L. Deluc, F. Ouaked-Lecourieux, M.R. Thomas, L.J.M. Torregrosa, OENO One, 53(2), 189-212 (2019) https://doi.org/10.20870/oeno-one.2019.53.2.2405

6. F. Ren, C. Ren, Z. Zhang, W. Duan, D. Lecourieux, S. Li, Z. Liang, Front. Plant Sci., 10(1), 612 (2019) https://doi.org/10.3389/fpls.2019.00612

7. W. Xu, F. Ma, R. Li, Q. Zhou, W. Yao, Y. Jiao, C. Zhang, J. Zhang, X. Wang, Y. Xu, Y. Wang, Plant Cell Environ., 42(11), 2979-2998 (2019) https://doi.org/10.1111/pce.13600

8. J. Zhao, Z.T. Li, J. Chen, R.J. Henny, D.J. Gray, J. Chen, Plant Cell Rep., 32(11), 17831793 (2013) https://doi.org/10.1007/s00299-013-1491-5

9. J. A. Garson, R.B. Ferns, P.R. Grant, S. Ijaz, E. Nastouli, R. Szypulska, R.S. Tedder, J. Virol. Meth., 186(1-2), 157-160 (2012) https://doi.org/10.1016/j.jviromet.2012.07.027 
10. R.K. Vangala, L. Singh， R.P. Gupta， Bioinformation， 8(13)，639-643 (2012) https://doi.org/10.6026/97320630008639

11. N.A. O'Leary, M.W. Wright, J.R. Brister, S. Ciufo, D. Haddad, R. McVeigh, B. Rajput, B. Robbertse, B. Smith-White, D. Ako-Adjei, A. Astashyn, A.Badretdin, Y. Bao, O. Blinkova, V. Brover, V.Chetvernin, J. Choi, E.Cox, O. Ermolaeva, C.M. Farrell, T. Goldfarb, T. Gupta, D. Haft, E. Hatcher, W. Hlavina, V.S. Joardar, V.K. Kodali, W. Li, D. Maglott, P. Masterson, K.M. McGarvey, M.R. Murphy, K. O'Neill, S. Pujar, S.H. Rangwala, D. Rausch, L.D. Riddick, C. Schoch, A. Shkeda, S.S. Storz, H. Sun, F. Thibaud-Nissen, I. Tolstoy, R.E. Tully, A.R. Vatsan, C. Wallin, D. Webb, W. Wu, M.J. Landrum, A. Kimchi, T. Tatusova, M. DiCuccio, P. Kitts, T.D. Murphy, K.D. Pruitt, Nucl. Acids Res., 44(1), 733-745 (2016) https://doi.org/10.1093/nar/gkv1189

12. G.M. Boratyn, C. Camacho, P.S. Cooper, G. Coulouris, A. Fong, N. Ma, T.L. Madden, W.T. Matten, S.D. McGinnis, Y. Merezhuk, Y. Raytselis, E.W. Sayers, T. Tao, J. Ye, I. Zaretskaya, Nucl. Acids Res., 41(1), 29-33 (2013) https://doi.org/10.1093/nar/gkt282

13. F. Sievers, D.G. Higgins, Curr. Protocols Bioinformat., 48(1), 3.13.1-3.13.16 (2014) https://doi.org/10.1002/0471250953.bi0313s48

14. F. Sievers, D.G. Higgins, In: K. Katoh (ed.) Multiple Sequence Alignment, 3-16 (Humana, New York, NY., 2021) https://doi.org/10.1007/978-1-0716-1036-7_1

15. S. Kumar, G. Stecher, K. Tamura, Mol. Bio. Evol., 33(7), 1870-1874 (2016) https://doi.org/10.1093/molbev/msw054 